\title{
Disclosure Practices of Mobile Telecommunication Companies with Special Reference to Grameenphone Ltd.
}

\author{
Taposh Kumar Neogy
}

Lecturer in Accounting, Department of Business Administration, Institute of Business Administration (Under National University), Rajshahi, BANGLADESH

\begin{abstract}
This discussion highlights on the measurement and analysis of the nature of disclosure of the Grameenphone Ltd. during the period under study. The annual reports of the Grameenphone Ltd. were analyzed to determine the extent to which contained the items of information included in the disclosure index of the Grameenphone Ltd. during the period under study. An index of disclosure has been constructed to measure the extent of disclosure of Grameenphone Ltd. For analyzing the nature of disclosure of Grameenphone Ltd. researcher have analyzed the different part of disclosure index such as company profile items, accounting policy items, balances sheet assets items, balance sheet liabilities items and income statement items both debit and credit items. This study shows that the disclosure score of the Grameenphone Ltd. is satisfactory and there was significant and not significant difference in disclosure score between the difference years during the period under study of various items of disclosure index.
\end{abstract}

Key-Words: Financial Disclosure, Mobile Telecommunication Company, Grameenphone Ltd, Bangladesh

\section{GEL Classification Code: M41; M48}

\section{INTRODUCTION}

The present world is the world of information technology. Mobile telecommunication is the revolutionary invention of science. This mobile has enriched our communication network. It has been possible to communicate from one corner to another by its contribution. There are six mobile telecommunication companies in Bangladesh such as Grameenphone Ltd, Banglalink, Aktel, City cell Ltd, Teletalk Ltd and newly established Airtle. Grameenphone Ltd. is the largest telecommunications service provider company in the Bangladesh. Grameenphone Ltd. has a dual purpose: to receive an economic return on its investments and to contribute to the economic development of Bangladesh where telecommunications can play a critical role. Grameenphone Ltd. believes in service, a service that leads to good business and good development. Grameenphone Ltd. is a private limited company incorporated in Bangladesh in 1996 under the Companies Act, 1994. Grameenphone Ltd. started its various activities on 26th March, 1997 for the customers 
through telemarketing and services to face the challenging situation in the competitive global telecommunication services in the context of Bangladesh. GrameenPhone Ltd. was initially registered as a private limited company and subsequently converted into a public limited company on 25 June 2007. During November 2009, GrameenPhone Ltd. listed its shares with both Dhaka and Chittagong stock exchanges.

Disclosure in financial reporting is the presentation of information necessary for the optimum operation of efficient capital market. As we know there are different users of accounting information. The users group needs accounting information to decide in their respective field of interest. The investor group requires information regarding investment feasibility. The creditors group requires information to form judgment regarding the credit worthiness of the borrows. Thus the needs for information of the different groups vary. So, a company has to meet the demand of users but it is a difficult task to meet the demand of all users because there are cost constraints. So, in the light of foregoing discussion disclosure means disseminating relevant financial information about the economic affairs of a business enterprise to the audience of interest. There are three types of disclosure like, full disclosure, fair disclosure, and adequate disclosure. In Bangladesh disclosure practices are mostly guided by the Companies Act, 1994, Securities and Exchange Rules, 1987 and the Accounting Standards adopted by the Institute of Chartered Accountants of Bangladesh. The quality of financial reporting in a country depends on the legal requirements governing disclosure together with professional recommendations which may have a varying degree of effectiveness depending on the influence of the professional bodies concerned (Marston: 1986). Disclosure is a part of revolutionary process. In a democratic setup, the demand for disclosure automatically increases. This is because all of the people directly or indirectly involved with the company in question will want to be able to quantify their risk. (Komatsubara: 1999). In some cases, information items were selected by the researchers for their disclosure indexes from a careful review of other studies of financial disclosure as well as after a review of recent annual reports of listed companies. In addition, the disclosure requirements relating to national accounting standards were considered and taken into account by these researchers in selecting items of information that ought to be disclosed by the companies and as such, where relevant, have been included in the disclosure index.

\section{JUSTIFICATION OF THE STUDY}

Economic development depends on some basic elements and telecommunication is one of them. The role of telecommunication in stimulating economic growth and improving the standard of living is beyond description. The contribution of telecommunication sector to economic development is very significant. The importance of telecommunication sector for the development of economy need not be exaggerated. Telecommunication plays a great role in business and commerce by facilitating the exchange of pertinent information. If information is not available then business executives can not take proper decision. So, abundance of telecommunication companies is a must for the development of business and commerce. So, the companies must survive in the economy. Grameenphone Ltd. is the third telecommunication company entering in Bangladesh and has been contributing to the expansion of telecommunication facilities in the country. It has network all over Bangladesh. Grameenphone Ltd. is the most renowned telecommunication service organization in Bangladesh. Grameenphone Ltd. has improved the communication skill in Bangladesh since 1997 and side by side other 
mobile phone companies are functioning such as Banglalink, Aktel, City Cell, Tele-Talk and Airtel. In our study an attempt has been made to examine the Disclosure Practices of Grameenphone Ltd. in Bangladesh. The study will be helpful to the customers, traders, businessmen, competitors, suppliers, users, vendors, and decision- makers, policymakers of the government, shareholders, researcher and others.

\section{ObJectives Of The Study}

The main objective of the study is to examine the disclosure practices of Grameenphone Ltd. in Bangladesh. The specific objective of the study is to find out the nature of disclosure score and to find out the affecting factors of disclosures score of Grameenphone Ltd.

\section{HYPOTHESIS OF THE STUDY}

Based on the review of related literature, the following hypotheses have been developed:

1. The profitability of the sample company does not affect the disclosure scores.

2. The size of the sample company does not affect disclosure scores.

\section{METHOdOLOGY OF THE STUDY}

A scientific approach to the research methodology is very much essential to evaluate the research problem systematically. This study has been considered various steps of analysis those are generally adopted by the research in studying research objectives along with logic behind them. Methodology helps to rely on empirical evidence, utilize relevant concepts, committed to only objective considerations, presuppose ethical neutrality that is aims at nothing but making only adequate and correct statement about population objects, results into probabilistic predictions, testing the conclusions through replication and aims at formulating most general axioms or what can be termed as scientific theories. Out of six mobile phone companies in Bangladesh, a sample of one Mobile Phone Company has been selected for the study. The selection of the mobile phone company is based on the convenience in data collection. The study mainly conducted on the basis of secondary sources i.e., journals, reports, economic review, annual reports of the Grameenphone Ltd. The data used in the article for the period from 2005 to 2009. Statistical tools like average, standard deviation, simple regression, multiple regression and T-test methods have been used for analyzing the data.

\section{CONSTRUCTION OF DisclosuRE INDEX}

The un-weighted disclosure index has been constructed which were used in the formulation of items of information. The items of information included in the disclosure index were selected according to the IAS (International Accounting Standard) adopted in Bangladesh Accounting Standard (BAS), Companies Act 1994, SEC (Securities and Exchange Commission) Ordinance-1987 and ICAB. The items of information included in the disclosure index are various heading such as company profile items, accounting policy items, Balance Sheet assets Items, balance sheet liabilities, income statement items both debit and credit and others. In constructing the un-weighted disclosure index dichotomous scoring for each of disclosure $=1$ and non-disclosure $=0$. Then the total of raw score is divided by the total number of items and multiplied by hundred to get the disclosure percentage. 


\section{REVIEW OF RELATED LiteratURES}

Ali and Haider (2008) wrote an article on Accounting and Disclosure System in Japan. The objective of this study is to give an overview on the accounting and reporting system in Japan. The authors concentrated on Generally Accepted Accounting Principles (GAAP) in Japan, Japanese so called triangular legal system, and the recent changes in Japanese accounting and reporting system. The accounting system in Japan is comprised of three different regulations, which prescribe financial accounting and reporting in Japan. These are the Commercial Code (CC), Securities and Exchange Law (SEL) and Corporate Income Tax Law. The Commercial Code (CC), Securities and Exchange Law (SEL) and Corporate Income Tax Law each have their own accounting requirements to address their peculiar objectives, but the three laws exert influence on each other in various ways. The three components are closely tied and have affected each other. In this sense, the accounting system in Japan is called as Triangular Legal System. The system is generally thought to be inefficient since the legal systems exercise reciprocal influence on each other in terms of offering useful financial reports by flexibly meeting requests for disclosure from the market. It is necessary to deal with this problem in order to achieve more useful financial reporting. Siddique and Raboul (2010) conducted an article on Disclosure Practices of Insurance Companies in Bangladesh: Study on Some Selected Insurance Companies. The main objective of the study is to examine the disclosure practices of Insurance Companies in Bangladesh. The specific objectives of the study are (i) to find out the adequacy of disclosure score and their interrelations with size and age of the selected insurance companies, (ii) to find out the extents of disclosures among the insurance companies and (iii) to provide suggestions for developing disclosure practices of the insurance companies. The disclosure practices have become more comprehensive overtime because of increasing awareness of the stakeholders. The present study evaluates the extent of disclosure practices relating to age and size of the insurance companies in Bangladesh covering a period of five years based on published annual audited reports and relevant reporting requirements. The major finding of the study is that the age and size of the insurance companies mostly affects the disclosure practices by them. Adequate disclosure practices by the small sized companies are desired. Insurance companies should also improve their disclosure practices regardless of their age.

Karim and Chowdhury (1998) wrote an article on A Study of the Association between Corporate Disclosure and Selected Corporate Attributes. The aim of the paper is to analyze the quality of disclosure measured by the disclosure index. This paper deals with the measurement and analysis of the extent of disclosure in annual reports by companies in Bangladesh and examines the association between disclosure levels and a number of corporate attributes. This study discussed some of the results of the annual report survey. The composition of the sample composition of the disclosure index and the weighting method were outline. The annual reports were scored using both the Singhvi index and Parry index to check the degree of consistency between the three indexes. On a crude means test it was found that the subsidiaries of MNCs disclose more than their domestic counterparts, clients of big audit firms of firms with international link disclose more than the clients of smaller audit firms or firms without an international link. The qualification of the company's accountant also appears to have a positive impact on disclosure. This study also showed that thirty three information items in the disclosure index were disclosed by less than $5 \%$ of companies and to that only twelve items were disclosed by 
more than $95 \%$ of companies. A sector-wise disclosure pattern indicates that disclosure levels were relatively higher in the banking, fuel and energy and pharmaceutical sector. Apart from the banking sector which includes only one multinational bank, the higher disclosure levels of the two other sectors could be largely attributed to the existence of MNC subsidiaries in the respective sectors. The final part of the paper was a comparison of the finding with those of Parry and Wallace.

Cooke (1992) wrote an article on The Impact of Size, Stock Market Listing and Industry Type on Disclosure in the Annual Reports of Japanese Listed Corporations. This research study represents a contribution to rigorous testing of Japanese financial reporting and specifically reports on the impact of size, stock market lasting and industry type on disclosure both voluntary and mandatory in the annual reports of Japanese listed corporations. It is found that size and listing status are important explanatory variables. In addition, manufacturing corporations were found to disclosure significantly more information than other types of Japanese corporations. The interaction between industry type and quotation status was also found to be significant.

Hossain (2008) conducted an article on The Extent of Disclosure in Annual Reports of Banking Companies: The Case of India. This study is an empirical investigation of the extent of both mandatory and voluntary disclosure by listed banking companies in India. It also reports the results of the association between company-specific attributes and total disclosure, i.e., mandatory and voluntary, of the sample companies. A total of 184 items were selected of which 101 and 81 were mandatory and voluntary respectively. The study revealed that in disclosing mandatory items, the average score is 88 , whilst the average score for voluntary disclosure is 25 . The findings also indicate that size, profitability, board composition, and market discipline variables are significant, and other variables such as age, complexity of business and asset-in-place are insignificant in explaining the level of disclosure. Results also indicate that Indian banks are very compliant with the rules regarding mandatory disclosure. In contrast, they are far behind in disclosing voluntary items. This paper has contributed to the academic literature, showing that the existence of a close monitoring system by regulatory authorities brings the potential for high compliance regarding disclosure and transparency, at least in mandatory cases. This study would be a good example for other developing countries, wanting to learn how Indian banks achieved this high level of compliance in mandatory disclosure.

Ahmed (1997) wrote an article on An Empirical Study of Disclosure Regulations in Emerging Countries. The purpose of this study is to assess empirically whether internal environmental variable have any impact on accounting disclosure regulations in developing countries. The environmental variables are type of economy, as measured by the relative contribution of the agriculture sector to the national GDP, equity market size and activity level, as measured by the proportion of market capitalization to the GDP; and total market turnover of shares traded; and two cultural variables, namely Uncertainty Avoidance and Individualism and multivariate approach was adopted to determine the degree of association between these indexes and the environmental variables. A number of economic variables such as per capita gross national product (GNP), level of government expenditures, net balance of trade, private sector consumption to relative to gross product, relative contribution of agriculture, relative capital formation, growth rate of GN, change in the foreign exchange rate and change in consumer price index have been identified to assess their impact on accounting practices. The research argues that since the accounting systems in developing countries are 
predominantly imposed by or imported from developed countries, rater that evolved within these countries, no significant relationships are expected to be found between disclosure regulations and internal environmental factors. The results are consistent with the hypothesis and the multiple regressions showed no significant association between disclosure regulations and the type of economy, equity market size and activity, and cultural factors. The findings provide further insights into the impact of the environments on accounting disclosure regulations in developing countries and support arguments that the accounting systems in these countries are not relevant to their environments.

\section{CONCEPTUAL FrameWORK}

Disclosure is crucial to the efficient allocation of scarce resources. In particular, disclosure of information is a major determinant of the allocation of investment funds to its most product uses. The purpose of disclosure is to provide relevant information which help to decision making process of various users for the particular needs. The regulating forces behind the financial reporting and disclosure are the Companies Act of 1994, the rules of the Securities and Exchange and the recommendations of the Institute of Chartered Accountants of Bangladesh. By disclosure, we refer to the effective communication of meaningful information. Providing information is the main task of disclosure the information which is useful for making business and economic decisions by the audience of interest and the rightful receivers or parties. The financial reporting process gets completion by the financial disclosure which is the end output of the whole process. The basic financial disclosure is consisted of the balance sheet, profit and loss account and the cash floe statement along with the supporting notes. Actually, accounting itself is an information system that needs financial statements as the end result. The summarized and classified reports of financial events are called financial statements. Actually, in a broader sense, a large number of integrated accounting processes providing periodic income, financial position and cash flow statements are the direct output of the financial statements (Mueller and Kelly: 1991). In making a decision, all financial statements contribute in varying degrees. The need for disclosure to audience of interest is essential because decisions related with investment, credit and similar things are based on it and these are the underlying objectives of financial reporting. The importance of disclosure is reflected in the evaluation of the serving purposes and the objectives of disclosure are truly focused on when one uses the accounting disclosure in decision making. The International Accounting Standards committee (IASC) describes financial statements in its Exposure Draft-28, framework for the preparation and presentation of financial statements, as Financial statements normally include a balance sheet, a profit and loss statement, a statement of changes in financial position, notes and other statements and explanatory material that are integral parts of the financial statements (IASC, 1998).

Information about an enterprise's resources obligation and earnings is reflected in a financial statement. The purposes of financial statements are truly served by giving useful information to users which can help them in making managerial and economic decisions. A definition, given by the Accounting Standard Steering Committee (ASSC, 1975) of UK and Ireland, says that a corporate financial report means the comprehensive package of information of all kinds which describes an organization's economic activity. Information which is useful is given by financial statements but it is corporate financial reports which give us detailed information. Both kinds of information relate directly or indirectly to the 
information provided by business enterprises' accounting system. Besides, providing basic financial statements, it provides both narrative and descriptive statements with frequently including illustrative materials. Financial reporting works as a way for providing information to users of all classes and this task completely indicates the economic activity of are organization. It has also been stated that financial reporting by the entities attempts to meet the needs of the external users of financial reports who lack authority to prescribe the financial information they want from entities (FASB, 1978).

In fact, in a broader sense, financial reporting includes, at the same time, financial statements and other means of communication information which are directly or indirectly related to the information provided by the accounting system. A focus on a precise financial report can show us that these kinds of report typically includes corporate annual reports, various statutory annual information full with regulatory commissions and registration statements for new security to be sold publicly (Mueller and Kelly, 1991). The management may exchange idea or communicate information to the outsiders of an enterprise by different means except the financial statements. The reasons may be of two kinds either the information required to be disclosed by authoritative pronouncement, regulatory rule of custom or the management considers it useful to these outsiders and discloses it voluntarily. Haniffa and Cook (2002) argued that the extent of disclosure is significantly influenced by structural complexity. And a farm is required for such complexities to have effective management information systems for monitoring purposes (Courtis, 1978; Cooke, 1989a). It is believed that the availability of such a system reduces the cost of information per unit which in turn arises the expectation of higher disclosure.

\section{ANALYSIS AND FINDINGS}

Table No. - 1

Table showing the year wise disclosure score of Grameenphone Ltd. during the study period

\begin{tabular}{|l|l|l|l|l|l|l|l|}
\hline Financial Year & 2005 & 2006 & 2007 & 2008 & 2009 & Average & SD \\
\hline Grameenphone Ltd. & 62.06 & 63.64 & 60.89 & 61.02 & 61.66 & 61.85 & 1.11 \\
\hline
\end{tabular}

(Source: Annual Reports of Grameenphone Ltd. from 2005 to 2009

Table -1 show the year-wise disclosure score of the Grameenphone Ltd. during the period under study. Researcher observes that the mean disclosure score of the GrameenPhone Ltd. is 61.85. The standard deviation of disclosure score of Grameenphone Ltd. is 1.11. In order to see whether there is no significant difference between the disclosure score in different years and researcher has conducted one sample $t$ test using SPSS. The result shows that $t$ value is 125.03 which is significant at 0.000 level. This indicates that there is significant difference between the disclosure score of the GrameenPhone Ltd. in different years. Researcher observes from the table that the disclosure score of the GrameenPhone Ltd. is satisfactory during the period under study.

Table No. - 2

Table showing the year wise disclosure score of Grameenphone Ltd. regarding company profile items

\begin{tabular}{|l|l|l|l|l|l|l|l|}
\hline Financial Year & 2005 & 2006 & 2007 & 2008 & 2009 & Average & SD \\
\hline Grameenphone Ltd. & 75.00 & 91.67 & 91.67 & 91.67 & 91.67 & 88.34 & 7.46 \\
\hline
\end{tabular}

(Source: Annual Reports of Grameenphone Ltd. from 2005 to 2009 
Table -2 shows the year-wise disclosure score regarding company profile items of the Grameenphone Ltd. during the period under study. Researcher observes that the mean disclosure of company profile items of the Grameenphone Ltd. is 88.34. The standard deviation of company profile items of Grameenphone Ltd. is 7.46. In order to see whether there is no significant difference between the company profile items in different years and researcher has conducted one sample $t$ test using SPSS. The result shows that $t$ value is 26.50 which are significant at 0.000 levels. This indicates that there is significant difference between the disclosures of company profile items of the GrameenPhone Ltd. in different years. Researcher observes from the table that the disclosure of company profile items of the GrameenPhone Ltd. is highly satisfactory.

Table No. - 3

Table showing the year-wise disclosure score of Grameenphone Ltd. regarding accounting policy items

\begin{tabular}{|c|l|l|l|l|l|l|l|}
\hline Financial Year & 2005 & 2006 & 2007 & 2008 & 2009 & Average & SD \\
\hline Grameenphone Ltd. & 54.76 & 52.38 & 52.38 & 54.76 & 54.76 & 53.81 & 1.30 \\
\hline
\end{tabular}

(Source: Annual Reports of Grameenphone Ltd. from 2005 to 2009)

From Table -3 shows the year-wise disclosure score of the Grameenphone Ltd. regarding accounting policy items during the period under study. Researcher observes that the mean disclosure of accounting policy items of the Grameenphone Ltd. is 53.81 during the period under study. The standard deviation of accounting policy items is 1.30 . This means that variance in disclosure of accounting policy items of Grameenphone Ltd. over the years under study is satisfactory. In order to see whether there is no significant difference between the accounting policy items in different years of Grameenphone Ltd. and researcher has conducted one sample $t$ test using SPSS. The result shows that $t$ value is 92.30 which is significant at 0.000 levels. This indicates that there is significant difference between the disclosures of accounting policy items of the Grameenphone Ltd. during the period under study.

Table No. - 4

Table showing the year wise disclosure score of Grameenphone Ltd. regarding balance sheet Assets items

\begin{tabular}{|l|l|l|l|l|l|l|l|}
\hline Financial Year & 2005 & 2006 & 2007 & 2008 & 2009 & Average & SD \\
\hline Grameenphone Ltd. & 67.38 & 67.38 & 67.86 & 67.38 & 68.48 & 67.70 & 0.49 \\
\hline
\end{tabular}

(Source: Annual Reports of Grameenphone Ltd. from 2005 to 2009)

From Table -4 we observe the year-wise disclosure score of the Grameenphone Ltd. regarding balance sheet asset items during the period under study. Researcher observes that the mean disclosure of balance sheet assets items of the Grameenphone Ltd. is 67.70. Thus researcher observes that Grameenphone Ltd. disclosed more on assets items during the period under study. The standard deviation of the Grameenphone Ltd. is 0.49 . In order to see whether there is no significant difference between the balance sheet assets items in different years and researcher has conducted one sample t test using SPSS. The result shows that $t$ value is 312.073 which is significant at 0.000 level. This indicates that there is significant difference between the disclosures of assets items of the GrameenPhone Ltd. in different years. Researcher observes from the table that the disclosure of balance sheet assets items of the Grameenphone Ltd. is satisfactory during the study period. 
Table No. - 5

Table showing the year-wise disclosure score of Grameenphone Ltd. regarding balance sheet Liabilities items

\begin{tabular}{|l|l|l|l|l|l|l|l|}
\hline Financial Year & 2005 & 2006 & 2007 & 2008 & 2009 & Average & SD \\
\hline Grameenphone Ltd. & 45.91 & 46.82 & 46.36 & 46.36 & 46.96 & 46.48 & 0.42 \\
\hline
\end{tabular}

(Source: Annual Reports of Grameenphone Ltd. from 2005 to 2009)

Table -5 shows the year-wise disclosure score of the Grameenphone Ltd. regarding balance sheet liabilities during the period under study. Researcher observes that the mean disclosure of liabilities items of the Grameenphone Ltd. is 46.48. The standard deviation of balance sheet liabilities items is 0.42 during the period under study. In order to see whether there is no significant difference between the balance sheet liabilities items of Grameenphone Ltd. in different years and researcher has conducted one sample t test using SPSS. The result shows that $t$ value is 248.51 which is significant at 0.000 levels. This indicates that there is significant difference between the disclosures of balance sheet liabilities items of the Grameenphone Ltd. in different years. Researcher observes from the table that the disclosure of balance sheet liabilities items of the Grameenphone Ltd. is not satisfactory during the period under study.

Table No. -6

Table showing the year-wise disclosure score of Grameenphone Ltd. regarding Income Statement Items (Both Debit and Credit)

\begin{tabular}{|l|l|l|l|l|l|l|l|}
\hline Financial Year & 2005 & 2006 & 2007 & 2008 & 2009 & Average & SD \\
\hline Grameenphone Ltd. & 58.18 & 58.18 & 58.76 & 58.76 & 59.16 & 58.61 & 0.42 \\
\hline
\end{tabular}

(Source: Annual Reports of Grameenphone Ltd. from 2005 to 2009)

From Table -6 highlights the year-wise disclosure score of the Grameenphone Ltd. regarding income statement items- (both debit and credit) during the period under study. Researcher observes that the mean disclosures of income statement items- (both debit and credit) of the Grameenphone Ltd. is 58.61 during the study period. The standard deviations of the income statement items- (both debit and credit) of the Grameenphone Ltd. is 0.42 during the period under study. In order to see whether there is no significant difference between the income statement items- (both debit and credit) of the Grameenphone Ltd. in different years and researcher has conducted one sample $t$ test using SPSS. The result shows that $t$ value is 309.48 which is significant at 0.000 levels. This indicates that there is significant difference between the disclosures of income statement items- (both debit and credit) of the Grameenphone Ltd. in different years. Researcher observes from the table that the disclosure of income statement items- (both debit and credit) of the Grameenphone Ltd. is satisfactory during the study period.

Profitability: Profitability was used by a number of researchers as an independent variable for fluctuations in disclosure level. Among these researchers Ahmed (2009), Inchausti (1997), Raffournier (1995), Wallace and Naser (1995) and Wallace (1987) found a positive association between profitability and the extent of disclosure whereas Belkaoui and Kahl (1978) found a negative association between the variables. In the present study gross profit, net profit, return on investment and return on equity as the measures of profitability. The following specific hypotheses have been tested regarding profitability: 


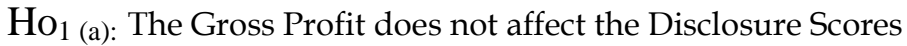

Table No. - 7

Disclosure Scores Vs Gross profit

\begin{tabular}{|c|c|c|c|}
\hline Sample & $\mathbf{R}^{\mathbf{2}}$ & F ratios & Significance Level \\
\hline Grameenphone Ltd. & 0.082 & 0.268 & 0.640 \\
\hline
\end{tabular}

(Source: Annual Reports of Grameenphone Ltd. from 2005 to 2009)

From Table 7 we see that R2 is 0.082 , F ratio is 0.268 and its significance level is 0.640 of the sample company. So, the null hypothesis is accepted the sample company. Thus, the study shows that the gross profit does not affect the disclosure scores of the sample company during the period under study.

$\mathrm{Ho}_{1}$ (b): The net profit does not affect the Disclosure Scores

Table No. - 8

Disclosure Scores Vs Net profit

\begin{tabular}{|c|c|c|c|}
\hline Sample \# & $\mathbf{R}^{\mathbf{2}}$ & F ratios & Significance Level \\
\hline Grameenphone Ltd. & 0.089 & 0.293 & 0.626 \\
\hline
\end{tabular}

(Source: Annual reports of Grameenphone Ltd. from 2005 to 2009)

From Table 8 we see that R2 is 0.089 , F ratio is 0.293 and its significance level is 0.626 of the sample company. So, the null hypothesis is accepted the sample company. Thus, the study shows that the net profit does not affect the disclosure scores of the sample company during the period under study

$\mathrm{Ho}_{1(\mathrm{c})}$ : The Return on Investment does not affect the Disclosure Scores

Table No. - 9

Disclosure Scores Vs Return on Investment

\begin{tabular}{|c|c|c|c|}
\hline Sample \# & $\mathbf{R}^{\mathbf{2}}$ & F ratios & Significance Level \\
\hline Grameenphone Ltd. & 0.373 & 1.785 & 0.274 \\
\hline
\end{tabular}

(Source: Annual Reports of Grameenphone Ltd. from 2005 to 2009)

From Table 9 we see that R2 is 0.373 , F ratio is 1.785 and its significance level is 0.274 of the sample company. So, the null hypothesis is accepted of the sample company. Thus, the study shows that the return on investment does not affect the disclosure scores of the sample company during the period under study.

$\mathrm{Ho}_{1}(\mathrm{~d})$ : The Return on Equity does not affect the Disclosure Scores

Table No. - 10

Disclosure Scores Vs Return on Equity

\begin{tabular}{|c|c|c|c|}
\hline Sample \# & $\mathbf{R}^{2}$ & F ratios & Significance Level \\
\hline GrameenPhone Ltd. & 0.373 & 1.785 & 0.274 \\
\hline
\end{tabular}

(Source: Annual Reports of Grameenphone Ltd. from 2005 to 2009)

From Table 10 we see that R2 is 0.403 , F ratio is 1.028 and its significance level is 0.250 of the sample company. So, the null hypothesis is accepted of the sample company. Thus, the study shows that the return on equity does not affect the disclosure scores of the sample company during the period under study

Size of Company: There are several studies which have been found a significant association between the size of the company and the extent of disclosure in the corporate 
annual report in both developed and developing countries such as Singhvi and Deai (1971), Buzby (1974), Chowm and Wong-Boren (1987), Cooke (1989), Wallace (1987), Ahmed and Nicholls (1994), Wallace and Naser (1995) and Inchausti (1997). In this study sales revenue, capital stock, current assets, fixed assets, total assets and shareholders' funds (Cooke, 1992) is used as the measures of size of company. The following specific hypotheses have been tested regarding size of the company:

$\mathrm{Ho}_{2}$ (a) : Sales Revenue does not affect Disclosure scores

Table No. -11

Disclosure Scores Vs Sales Revenue

\begin{tabular}{|c|c|c|c|}
\hline Sample Company & $\mathbf{R}^{2}$ & F ratios & Significance Level \\
\hline Grameenphone Ltd. & 0.415 & 4.957 & 0.061 \\
\hline
\end{tabular}

(Source: Annual Reports of Grameenphone Ltd. from 2005 to 2009)

From Table - 11 we see that R2 is 0.415 , F ratio is 0.4 .957 and its significance level is 0.061 of the sample company. So, the null hypothesis is accepted of the sample company and the study shows that the sales revenue does not affect the disclosure scores of the sample company during the period under study.

$\mathrm{Ho}_{2}$ (b): The Capital Stock does not affect the Disclosure Scores

Table No. - 12

Disclosure Scores Vs Capital Stock

\begin{tabular}{|c|c|c|c|}
\hline Sample Company & $\mathbf{R}^{\mathbf{2}}$ & F ratios & Significance Level \\
\hline GrameenPhone Ltd. & 0.165 & 0.591 & 0.498 \\
\hline
\end{tabular}

(Source: Annual Reports of Grameenphone Ltd.' from 2005 to 2009)

From Table 12 we observe that R2 is 0.165 , F ratio is 0.591 and its significance level is 0.498 of the sample company. So, the null hypothesis is accepted of the sample company and the study shows that the capital stock does not affect the disclosure scores of the sample company during the period under study.

$\mathrm{Ho}_{2}$ (c): The Current Assets does not affect the Disclosure Scores

Table No. - 13

Disclosure Scores Vs Current Assets

\begin{tabular}{|c|c|c|c|}
\hline Sample Company & $\mathbf{R}^{\mathbf{2}}$ & F ratios & Significance Level \\
\hline Grameenphone Ltd. & 0.315 & 1.380 & 0.325 \\
\hline
\end{tabular}

(Source: Annual Reports of Grameenphone Ltd. from 2005 to 2009)

From Table 13 we observe that R2 is 0.315 , F ratio is 1.380 and its significance level is 0.325 of the sample company. So, the null hypothesis is accepted of the sample company and the study shows that the current assets do not affect the disclosure scores of the sample company during the period under study.

$\mathrm{Ho}_{2}(\mathrm{~d})$ : The Fixed Assets does not affect the Disclosure Scores

Table No. - 14

Disclosure Scores Vs Fixed Assets

\begin{tabular}{|c|c|c|c|}
\hline Sample Company & $\mathbf{R}^{\mathbf{2}}$ & F ratios & Significance Level \\
\hline GrameenPhone Ltd. & 0.878 & 21.625 & 0.019 \\
\hline
\end{tabular}

(Source: Annual Reports of Grameenphone Ltd. from 2005 to 2009) 
From Table 14 we observe that R2 is 0.878 , F ratio is 21.625 and its significance level is 0.019 of the sample company. So, the null hypothesis is rejected of the sample company and the study shows that the fixed assets affect the disclosure scores of the sample company during the period under study.

$\mathrm{Ho}_{2}(\mathrm{e}):$ The Total Assets does not affect the Disclosure Scores

Table No. - 15

Disclosure Scores Vs Total Assets

\begin{tabular}{|c|c|c|c|}
\hline Sample Company & $\mathbf{R}^{\mathbf{2}}$ & F ratios & Significance Level \\
\hline Grameenphone Ltd. & 0.339 & 1.542 & 0.303 \\
\hline
\end{tabular}

(Source: Annual Reports of Grameenphone Ltd. from 2005 to 2009)

From Table 15 we see that R2 is 0.339 , F ratio is 1.542 and its significance level is 0.303 of the sample company. So, the null hypothesis is accepted of the sample company. Thus, the study shows that the total asset does not affect the disclosure scores of the sample company during the period under study.

$\mathrm{H}_{2}$ (f): Shareholders' equity fund does not affect the disclosure score

Table No. - 16

Disclosure Scores Vs Shareholders Equity Fund

\begin{tabular}{|c|c|c|c|}
\hline Sample Company & $\mathbf{R}^{\mathbf{2}}$ & F ratios & Significance Level \\
\hline Grameenphone Ltd. & 0.037 & 0.116 & 0.756 \\
\hline
\end{tabular}

(Source: Annual Reports of Grameenphone Ltd. from 2005 to 2009)

From Table 16 we see that $\mathrm{R} 2$ is $0.037, \mathrm{~F}$ ratio is 0.116 and its significance level is 0.756 of the sample company. So, the null hypothesis is accepted of the sample company. Thus, the study shows that the shareholders equity does not affect the disclosure scores of the sample company during the period under study.

\section{Multiple Regression Models}

Multiple linear regression techniques are used to test two alternative versions of each hypothesis. The model is created using UDI as the dependent variable.

$$
\begin{aligned}
U D I= & \alpha+\beta_{1} T A+\beta_{2} G R+\beta_{3} N O B+\beta_{4} E P S+\beta_{5} R O A+\beta_{6} R O I+ \\
& \beta_{7} N P M+\beta_{8} C D R+\beta_{9} C A R+\beta_{10} D E R+\beta_{11} S R R+\varepsilon
\end{aligned}
$$

Where UDI $=$ total score received by each sample bank under un-weighted disclosure index;

$$
\begin{aligned}
& \alpha=\text { the constant, and } \\
& \varepsilon=\quad \text { the error term. }
\end{aligned}
$$

Regressional Studies of Disclosure Score vs. all Independent Variables

$\mathrm{Ho}_{1}(\mathrm{e})$ : The gross profit, net profit, return on investment and return on equity do not affect the Disclosure Scores

Table No. - 17

Disclosure Scores Vs All Independent Variables

\begin{tabular}{|c|c|c|c|}
\hline Sample Company & $\mathbf{R}^{\mathbf{2}}$ & F ratios & Significance Level \\
\hline Grameenphone Ltd. & 1.000 & 0 & 0 \\
\hline
\end{tabular}


From Table 17 we observe that $\mathrm{R}^{2}$ is 1.000 , F ratio is 0 and its significance level is 0 of the sample company. So, the null hypothesis is rejected of the sample company and the study shows that the gross profit, net profit, return on investment and return on equity do not affect the disclosure scores of the sample company during the period under study.

$\mathrm{Ho}_{2}(\mathrm{~g})$ : The sales revenue, capital stock, current assets, fixed assets, total assets and shareholders' funds do not affect the Disclosure Scores

Table No. - 18

Disclosure Scores Vs All Independent Variables

\begin{tabular}{|c|c|c|c|}
\hline Sample Company & $\mathbf{R}^{\mathbf{2}}$ & F ratios & Significance Level \\
\hline Grameenphone Ltd. & 1.000 & 0 & 0 \\
\hline
\end{tabular}

From Table 18 we see that R2 is $1.000, \mathrm{~F}$ ratio is 0 and its significance level is 0 . So, R2 is significant which means that our null hypothesis is rejected of the sample company. So, we can comment that the sales revenue, capital stock, current assets, fixed assets, total assets and shareholders' funds do not affect the Disclosure Scores of the sample company during the period under study.

\section{Conclusion AND Recommendations}

The present study evaluates the nature of disclosure practices and identifies the factors affecting of disclosure score of Grameenphone Ltd. Research has analyzed the different parts of disclosure index and results of this discussion, the average disclosure of company profile items is 88.34 percentage, the average disclosure of accounting policy items is 53.81 percentage, the average disclosure of balance sheet assets items is 67.70 percent, the average disclosure of balance sheet liabilities items is 46.48 percentage and the average income statement items both debit and credit is 58.61 percentage during the period under study. Research has selected some independent variables for analyzing the affecting factors of disclosure scores such as profitability and firm size. The surrogates of profitability are net profit, return on equity and return on investment. The surrogates of firm size are operating revenue, total assets and shareholders fund and debt equity ratio. The regressional result of our study is that gross profit does not affect the disclosure score, net profit does not affect the disclosure scores, return on investment does not affect the disclosure scores, return on equity does not affect the disclosure scores, sales revenue does not affect the disclosure scores, capital stock does not affect the disclosure scores, current assets do not affect the disclosure scores, fixed assets affect the disclosure scores, total assets does not affect the disclosure score, shareholders fund does not affect the disclosure scores and debt ratio does not affect the disclosure scores during the period under study. A company should develop a sound financial reporting system for its own interest. Financial performance and position of Grameenphone Ltd. is measured on the basis of financial information which is used in the financial reporting system. Disclosure of accounting information is a necessity for better financial reporting of the Grameenphone Ltd. An attempt has been made in this study to measure the extent of disclosure practices by the Grameenphone Ltd. The disclosure scores of Grameenphone Ltd. is satisfactory. This study highlights that the disclosure score of company profile items, accounting policy items, balance sheet assets items and income statement items both debit and credit is higher than balance sheet liabilities items of the Grameenphone 
Ltd. during the period under study. Disclosure practices of various information Grameenpone Ltd. follows accounting standard adopted by ICAB, The Companies Act, Security and Exchange rules and others applicable laws. Management attribute is very much important to disclose the available information in the financial statement such as if the attribute is conservative the financial disclosure will be poor. However, it is the demand of time to disclose more information to satisfy the various kinds of users. Only a sound financial reporting system with good governance can bring or maintained the confidence of the investors. It is evident from the findings of our study that a disclosure practice of Grameenphone Ltd. is satisfactory during the study period.

\section{BiBLIOGRAPHY}

Ahmed (2009), "Compliance of Financial Disclosure in the Corporate Annual Reports of Banking Sector of Bangladesh", Published Ph. D. Dissertation, Rajshshi University

Ahmed (1997), an Empirical Study of Disclosure Regulations in Emerging Countries, The Indian Journal of Commerce, Vol. L, No. 191, Part II June

Ahmed and Nicholls (1994), "The Impact of Non-financial Company Characteristics on Mandatory Compliance in Developing Countries: The Case of Bangladesh", the International Journal of Accounting, vol. 29, no. 1

Ali and Haider (2008), Accounting and Disclosure System in Japan, the Bangladesh Accountant, July - September

Annual Reports of GrameenPhone Ltd. from 2005 to 2009

A.Z.M. Anisur Rahman and Quazi Mohammad Galib Ahsan, (1993), “Full disclosure: A defense of the disclosure of Accounting Policies", Accounting Disclosure, The Cost and Management, May-June, p-36

Belkaoui and Kahl (1978), "Corporate Financial Disclosure in Canada", Research Monograph No. 1 (Vancouver: Canadian Certified General Accountants Association)

Belel (2000), Disclosure in Corporate Reports - A Review with Special Reference to Bangladesh, Buxby (1974), "Selected Items of Information and Their Disclosure in Annual Reports", the Accounting Review, July

Chow and Wong-Boren (1987), "Voluntary Financial Disclosure by Mexican Corporation", the Accounting Review

Cooke (1989), "Disclosure in the corporate Annual Reports of Swedish Companies", Accounting and Business research, Vol. 19, no. 74

Eallace and Naser (1995), "Firm Specific Determinants of the Comprehensiveness of Mandatory Disclosure in the Corporate Annual Reports of Firms Listed on the Stock Exchange of Hong Kong", Journal of Accounting and Public Policy, volume 14

Financial Accounting Standards Board (FASB), (1981), Annual Report of the Financial Accounting Standards Board (Stamford, Connecticut: FASB).

Hossian A. K., et. al. (2008), "Financial Performance of GrameenPhone Ltd.: An overview", Islamic University Studies (Part - c), Volume 7, No. 2, June

Hossain, Z. S. and Islam, S. K. (1998), "Disclosure of Accounting Policies in the Financial Statements of the Insurance Companies in Bangladesh", Journal of the Institute of Bangladesh Studies, Volume 21, University of Rajshshi.

Hossain, (2010), "Financial Reporting Practices of Listed Pharmaceutical Industry in Bangladesh", Unpublished Ph. D Thesis, National University. 
Hossain (2008), the Extent of Disclosure in Annual Reports of Banking Companies: The Case of India, European Journal of Scientific Research, ISSN 1450- 216X Vol. 23 No. 4

Inchausti (1997), "The Influence of Company Characteristics and Accounting Regulations on Information Disclosed by Spanish Firms", The European Accounting Review, Vol. 1 No. 1

Institute of Chartered Accountants of Bangladesh (ICAB), Bangladesh Accounting Standards (BAS), Volume I and II. Dhaka: ICAB

International Accounting Standards Board (IASB) (2001), Framework for the Preparation and Presentation o Financial Statements (London: IASB).

Karim and Chowdhury (1998), A Study of the Association between Corporate Disclosure and Selected Corporate Attributes, Finance and Banking, Vol. 4, Number 1 \& 2, June

Komatsubara, Akira (1999), "The Disclosure Practices of Life Insurers", Nli Research Institute, No.127, pp, $23-28$.

Islam, S. K. (2000), "Qualitative Characteristics of Financial Disclosure of the Commercial Banks in Bangladesh", Journal of the Institute of Bangladesh Studies, Volume 23, University of Rajshahi

Martson and Shrieves P.J. (1991) "The use of disclosure Indices in Accounting Research: A Review Article," British Accounting Review, Vol.23, pp, 32 - 43.

Marston, C. L. (1986), Financial Reporting Practices in India. London: Croom Helm.

Pramanik and Islsm (1999), Disclosure of Accounting Policies: A Study of the Commercial Banks in Bangladesh, Thoughts on Economics, Vol. 9, No. 1 \& 2, ISSN 0256 8586, Jan - June.

Parry M. J. and Groves, R. E. (1990), "Does Training More Accountants Raise the Standards of Accounting in Third World Countries? A Study of Bangladesh", In R. S. O. Wallace, John M. Samuels and Richard J. Briston (eds.), Research in Third World Accounting"

Siddique and Raboul (2010) Disclosure Practices of Insurance Companies in Bangladesh: Study on Some Selected Insurance Companies, the Cost and Management, May-June

Raffournier (1995), “The Determinants of Voluntary Financial Disclosure by Swiss Listed Companies", The European Accounting Review, Vol. 4, No. 2.

Singhvi and desai (1971), "An Empirical Analysis of Quality of Corporate Financial Disclosure", The Accounting Review, January

Singhvi, S. S. (1967), "Corporate Disclosure through Annual reports in the USA and India" (Unpublished Doctoral Dissertation, Graduate School of Business, Columbia University)

Singhvi, S.S (1968), "Characteristics and Implication of Inadequate Disclosure: A Case Study of India". The International Journal of Accounting Education and Research, Vol. 3 No. 2 Spring, pp, 29 - 44

Saha and Rahman (2000), "Financial Reporting Practices in Banks and Financial institutions: Implementing the New Formats of Financial Statements in Compliance With IAS-30", the Bangladesh Accountant, July - September.

Wallance, R. S. O. (1987), “Disclosure of Accounting Information in Developing Countries: A Case Study of Nigeria", Ph. D Thesis, University of Exeter, Devon.

Wallace (1987), "Disclosure of Accounting Information in Developing Countries: A Case Study of Nigeria", Doctoral Dissertation, University of Exeter, Devon. 